\title{
Outdoor Learning as the Development of Eco Literacy Skills in Learning Social Studies in Secondary School
}

\author{
$1^{\text {st }}$ Ratna Puspitasari* \\ State Institue for Islamic Studies (IAIN) \\ Syekh Nurjati Cirebon, Indonesia \\ puspitasarinana72@gmail.com
}

\author{
$2^{\text {nd }}$ Khomarudin \\ State Institue for Islamic Studies (IAIN) \\ Syekh Nurjati Cirebon, Indonesia \\ oemarbakrie0231@gmail.com
}

\begin{abstract}
Ecoliteracy among junior high school students in the city of Cirebon as a basic ability possessed by students regarding the understanding of the basic ecological, student ecology and the concept of sustainability (sustainable) school environment as a tool to solve problems. Increasing student eco-literacy is a goal in social studies learning so that students have the awareness, sensitivity, so that the environment needs to be safeguarded, managed and utilized for the present as well as for the future in order future generations have the right to enjoy the environment. The researcher using random sampling. The data were gathered from students of Junior High
\end{abstract}

\section{INTRODUCTION}

Social studies education at the school level with learning activities becomes one of the means in developing students' potential and abilities. The ability of students who are very diverse should be sourced and lead to efforts to improve themselves, families, including the natural environment in the local, national and global scope. One aspect that must be developed is the ability relating to the relationship of students as individuals or humans with the natural environment around or better known as illiteracy abilities [1].

Etymologically, eco-literacy comes from the words eco and literacy. Eco stands for ecology which means a branch of natural science that discusses the study of habitats and interactions between living things and the surrounding
School 7in Cirebon and Private Junior High School Nurshiddiq Cirebon through observation, documentation, and phenomenon activities as the collecting data technique. The result of this research shows that habituation as early as possible is carried out by junior high school social studies education teachers in the city of Cirebon and parents so that students become more ecologically literate. Lack of respect for the environment has become a habit that has started to develop in social studies.

Keywords-Eco-Literacy, Social Studies, Learning

environment. Ecology not only studies the structure and function of nature but also studies the analysis and solutions related to some forms of natural phenomena [2](Zulkifli, 2014). Meanwhile, literacy implies freedom or freedom from blindness. Therefore, ecoliteracy in social studies learning in general means as a form of awareness, understanding and literacy towards social studies science with an environmental background.

Daniel (2016) describe that ecoliteracy is a basic ability that a person has regarding the basic understanding of ecology, human ecology and the concept of sustainability (sustainable) environment as a tool to solve problems[3]. Increasing eco-literacy is a goal in social studies learning so that students have the awareness, sensitivity or sensitivity that the 
environment needs to be safeguarded, managed and utilized for the present as well as for the future where future generations have the right to enjoy the environment. Habituation in social studies learning as early as possible is done by both teachers and parents so that students become ecologically literate.

The eco-literacy ability of students can be built strongly when teachers and schools provide support as the spearhead of education. As part of the academic community, researchers have concerns about environmental education carried out in junior high schools and vocational schools that still lack eco-literacy abilities. This student's lack of ability is caused by several things including the usual getting material that tends to be theoretical and less applicative. In addition, the lack of a teacher's ability to arouse students' creativity in creating products from school waste is related to their daily lives. Environmental factors that are not good include being far from strategic places as well as the environment which is dirty and does not respect the environment.

Lack of respect for the environment has become a habit that has started to develop in social studies. This results in reduced ecoliteracy abilities of school residents, especially students due to unfavorable environmental influences. This is the background of the emergence of ideas to research in order to obtain a learning formula that accustoms and is even able to civilize students in order to improve students' eco-literacy towards themselves and their environment through outdoor systems.

One of the applications of eco-literacy capabilities to students can be applied in formal schools. Lickona gives the reason that school is one of the means in changing the character and agents of reform [4]. Schools are expected to be the leading agents in helping social and environmental problems. The way most schools apply social studies learning in order to improve the ability of students, usually only in the form of appeals and verbal instructions that lack the desired impact. Therefore, more concrete techniques or learning strategies are needed to improve the ability of eco-literacy.

Based on the background of the above problems, the researcher is interested in conducting research on out door-based ecoliteracy skills in social studies learning in junior high schools in Cirebon. The formulation of the problem in this study includes:how is the background of eco-literacy skills applied in junior high schools in Cirebon?, how is the implementation of outdoor-based eco-literacy skills in social studies learning to be applied?, what are the obstacles faced by teachers and students in implementing outdoor-based ecoliteracy?

\section{International Journal about Literacy}

Building Eco-literacy through Adiwiyata Program (Study at Adiwiyata School in Banda Aceh By Mirza Desfandi, Enok Maryani, Disman), this study is backgrounded by the importance eco-literacy for each individual. One of comprehensive effort to build ecoliteracy in the community is through Adiwiyata Program. This study aimed is to find out how the effectiveness builds students'ecoliteracy in Banda Aceh. The method which is used surveys. The study is conducted in ten schools, with respondents are principal, teachers, administrative staff and students.

Data analysis is done descriptively toward five variables and hypothesis tests use nonparametric statistic tests. The result of the study showed that there is significant influence of school policy, curriculum implementation, school culture and school infrastructure management toward student's eco-literacy. The finding of the study is the more effective four components of Adiwiyata is implemented, the higher of student'seco-literacy. Therefore, four implemented maximally, among others by strengthening Adiwiyata school team.

\section{Eco Literacy Based on Outdoor}

Literacy means a person's ability to use their potential and skills in processing and understanding information when reading and writing.Another opinion says that understanding literacy is an individual's ability to process and understand information when 
reading and writing. In other words, literacy is a set of skills and abilities in reading, writing, counting, and solving problems in their daily lives.Etymologically, the term literacy comes from the Latin word 'literatus', which means that people are learning. In this case, the meaning of literacy is closely related to the process of reading and writing.

Schools have an important role in developing literacy skills. All school activities should be integrated into the School Literacy Movement (SLM). Included in this is how to integrate literacy into social studies learning. Because in the guidelines released by the Ministry of Education and Culture there are three stages of GLS namely habituation, social studies development and learning as well as learning other subjects. Habituation is the initial step for social studies teachers in integrating literacy into learning. If habituation can already be implemented by the teacher, students with the support of the school, the second step is the development of social studies learning through materials, media, and learning models that fit the needs of students.

Sumarlin (2013) called the integration of literacy in learning to shape the attitudes and skills of students in managing information [5]. During the learning process, students become accustomed to carrying out scientific procedures. Where they have to search, understand, process, conclude and recommunicate the information obtained.

\section{Steps for Outdoor Study Learning}

Spinola(2015) explains the steps and roles that need to be done by the teacher in the implementation of learning outside the classroom (Outdoor Study) consisting of the preparation phase, the implementation stage, and the evaluation stage [6].

Preparation Phase, continue the following steps: the teacher and students together formulate the objectives of social studies learning, the teacher prepares a place and media that are outside the social class classroom environment, the teacher invites students outside the classroom, and teachers and students must be comfortable, relaxed and disagree.

Implementation Phase, continue the following steps: the teacher instructs students to learn neatly and orderly to study in an outside classroom, the teacher stands face to face with students about 1 meter away where there is a conversation between teacher and student and student and student, the teacher explains the social studies learning material, students pay attention to the teacher's explanation outside the classroom, in the schoolyard or in an open field, attractions associated with, and the teacher gives the opportunity for students to ask questions.

Evaluation Phase in social studies learning describes the following steps: the evaluation phase is an opportunity given by the teacher for students to support their progress. If students do not provide answers, the teacher does not say wrong asking for the correct words and invites students to repeat again.

\section{Learning Objectives Outside the Classroom (Outdoor Study)}

The purpose of learning outside the classroom (outdoor study) that you want to learn through activities outside the classroom or outside the school environment. Sumarlin (2013) quotes that the learning objectives outside the classroom are as follows: make everyone have a unique opportunity to develop creativity and personal promotion, provides a meaningful setting (setting) for attitude setting, helps realize the potential of each individual so that his soul, body, and spirit can develop optimally, welcoming opportunities for student participants to get directly to the material presented, invites students to develop social studies learning and have an interest in activities outside the classroom, help contribute to developing better teacher-student relationships through a variety of experiences in the wild, learning opportunities to learn from direct experience, and utilizing resources from the surrounding environment and community for social studies learning [7]. 


\section{METHOD}

Phenomenology research tries to explain or uncover the meaning of concepts or phenomena of experience based on the consciousness that occurs in some individuals. According to Creswell (2011), the phenomenological approach postpones all judgments about natural attitudes until a certain basis is found [8]. This delay is usually called an epoche (time period). The concept of epoche is to differentiate the data area (subject) from the researcher's interpretation. The epoche concept becomes the center where the researcher compiles and groups initial allegations about phenomena to understand what is mentioned by respondents.

The Phenomenology Method, according to Polkinghorne (Creswell, 2013) that phenomenology describes the meaning of life experience for some people about a concept or phenomenon [9]. Meanwhile, according to Husserl in Creswell (2013), phenomenological researchers try to look for things that are necessary (essential), invariant structure (essence) or the meaning of experience that is fundamental and emphasizes the intensity of consciousness where experience consists of things that appear from the outside and things that are in each awareness based on memory, image and meaning [10].

Phenomenology is a term that is widely used in terms of modern philosophy, which has the subject of "phenomena". Kant was the first to discuss this problem by giving the name phenomenology (phenomenology). Jeynes (2010) uses the term phenomena for imaginary depictions of human experience, then defines phenomenology as a "theory of delusion" [11].

The research is conducted in the junior high school Cirebon. The researcher using random sampling. The Population as the students of junior high school in Cirebon. The sample is the students of state junior high school 7 Cirebon, and private junior high school Nurshiddiq Cirebon. The writers use the observation, documentation, and phenomenon activities as the collecting data technique. The writers analyze the result of the observation, document, and phenomenon.

\section{RESULTS AND DISCUSSION}

\section{Background Outdoor-Based Eco-Literacy Skills Applied in Junior High Schools in Cirebon City}

One of the missions of the $21^{\text {stcentury }}$ education that applies tojunior high schoolsthroughout the City of Cirebon is to build ICT literacy skills and media in students. This mission can be achieved in developing areas even though some schools do not yet have ICT learning facilities. This condition does not prevent the implementation of $21^{\text {stcentury }}$ learning because the internet has already reached developing regions. The next effort is the acquisition of information via the internet that supports teachers and students building skills such as ICT skills. However, it is necessary to strengthen student character education so that the use of ICT is carried out appropriately.

For teachers in Cirebon City junior high schools, one of the solutions of $21^{\text {stcentury }}$ learning is to participate in utilizing a portal developed by the Education Information and Communication Technology Center as well as several other media to accommodate the aspirations of teachers. One such education portal is known as "Rumah Belajar" (https:// belajar.kemdikbud.go.id). The learning house provides interactive learning materials and facilitates communication and interaction between communities. The eight main features of the learning house: (1) learning resources; (2) electronic school books; (3) question bank; (4) virtual laboratories; (5) cultural maps; (6) spacecraft roaming; (7) sustainable profes sional development; and (8) virtual classes. In addition, there are three supporting features, namely: (1) community work; (2) the teacher's work; and (3) language and literary works. The eleven features are designed to support

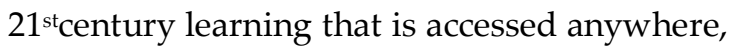
anytime with anyone.

For social studies education teachers in the city of Cirebon, activities utilizing the educa tional portal facilitated by the government 
greatly contribute to developing their knowledge from various sources. The application of $21^{\text {st }}$ century learning in developing regions must adapt the educational content of the 4.0 industrial revolution era so that teachers must be digital literate. Learning content is expected to fulfill $21^{\text {st }}$ century skills, namely: (1) learning and innovation skills include mastery of knowledge and diverse skills, learning and innovation, critical thinking and problem solving, communication and collaboration, and creativity and innovation;

(2) digital literacy skills include information literacy, media literacy and ICT literacy; (3) career and life skills include flexibility and adaptability, initiative, social and cultural interaction, productivity and accountability, and leadership and responsibility [12]. In the end, education produces a productive genera tion of the nation so that the problems of unemployment and competitiveness of human resources are minimized. The teaching profession of social studies education in most of the schools studied in junior high schools in the city of Cirebon is not without problems, the teaching profession is a profession that requires creativity, innovation, and vision, including in developing teaching materials to attract students' interests. However, social studies teacher must be able to get out of all kinds of problems, the solution is a choice that does not harm you as a teacher as well as a drug for students to be able to accept the changes you create. This makes it easier for social studies education teachers to find solutions to environmental problems where the problems they face are the repetition of those previously encountered.

\section{Implementation of outdoor-based eco-literacy skills in social studies learning}

Implementation of outreach-based ecoliteracy skills in social studies learning needs to be applied by social studies teachers including teachers naturally have a list or list of problems and environmental solutions based on student character in general, and if needed teachers can also make itspecifically so that the results of student learning development can be maximized as expected.
Student character

Social studies teacher recognizes that each student has his own character, which cannot be compared to others, this law also applies to students. Twenty students faced by social studies education teachers, then social studies educationteachers are dealing with twenty characters as well. The teacher tries to find a few similarities to support the application of social studies learning models and methods, the formulation of the applied approach strategy and so forth.

Attitudes and behavior

Actions and actual behavior are also part of the character possessed by students, but this is more focused again because of all the characters possessed by students, attitudes and behavior are the most influential and influence the culture of students in school.

\section{Interest and talent}

Social studies teachers are required to discover students' talents and interests. Channeling the talents and interests of students appropriately can increase student motivation. Otherwise, it will cause problems for social studies teachers, schools and students themselves. Students who have hidden talents and are interested in social studies learning generally become students who are aggressive, fight and like to do negative actions that violate school rules. The symptoms of student delinquency that arise are not responded negatively but should be appreciated properly and prevented so that it does not cause a new form of delinquency.

\section{Students absorption}

The obstacles that are often faced by social studies teachers include the low level of student absorption of social studies subject matter, which will disrupt teacher plans, allocation of study time, and so forth. Social studies teachers basically do not discredit students too fast because of the delay in receiving material, but as far as possible the social studies teacher tries to find the right strategy that can encourage students to 
maximize the ability to receive and absorb the social studies education material being taught.

Lack of student discipline

Discipline is a determining factor for the success of social studies learning in implementing outdoor-based eco-literacy, discipline in time, discipline in the assignment, discipline in the learning process and so on. Social studies teachers who teach in classrooms where students have a high level of discipline are more pleasant than teaching in classrooms with students who have low discipline. However, social studies teachers never give up with this problem, teachers try to restore student discipline so that social studies learning goes as expected.

Students are too passive

Social studies teachers often find situations where students in the class, whether asked or not, remain silent. This situation makes it difficult for the teacher, the teacher is difficult to ensure that they have understood and understood the material or not. The solution, of course, must be to provoke them to become active so that you can read and analyze the extent of their acceptance of the material being taught.

Not calm in the classroom

Although the number is very small, this social studies learning activity is quite disturbing to the teacher and other students. Social studies teachers try to find a solution, by not blaming students too quickly because there was one case in the three schools studied that the source of the problem was the teacher. Among them when the social studies teacher, teaching is monotonous and too boring, the way the social studies teacher communicates is unclear, the material is too dense, or other situations such as the room is too hot, many disturbances from outside, tables and chairs are not pleasant and so forth.

Student confidence in the teacher

One of the successes of social studies learning in junior high schools in the city of Cirebon, among others, is the belief of students in social studies education teachers. The belief referred to is that they did not learn wrong from the teacher because the teacher mastered social studies education material so that they encouraged them to love the lessons the teacher taught.

Praise

The results showed that some students were actually thirsty with praise from social studies teachers, but conditions in the field showed that many social studies teachers ignored it because it focused more on completing subject matter. The results of interviews with several respondents indicated this was due to the lack of praise that he received so as to reduce student learning motivation while learning motivation was one of the determining factors for the success of social studies learning.

Just following along

Surveys, interviews and document studies explain that many students only position themselves behind, they don't want to be ahead. Teachers easily find students like this, they always try to sit in the back, do not want to sit in front. Social studies teachers will have difficulty starting learning if students do not have the initiative to do; moreover the current educational paradigm has changed from "being told" to "finding out".

Conditions in this field are in line with the thinking of Pidarta (2009) which states that classroom management problems related to student behavior are: lack of unity, including the existence of groups, cliques, and gender disputes [13]. There is no standard behavior in group work in social studies class, for example noisy, chatting, going here and there, and so on.Negative reactions to members of the learning group, for example, noisy, hostile, isolating and degrading stupid groups. Classes tolerate the mistakes of their friends, accept, and encourage the erroneous behavior of students. Easy to react to negative things / disturbed, for example when visited by monitors, guests, climate change, and so on. Low morale, hostility, aggression, for example in schools with lack of learning tools, lack of money, and others. Not being able to adapt to a changing environment, such as additional 
assignments, new social studies class members, new situations, and so on.

Based on the results of the research described above, it can be understood that the role of social studies education teachers is very important in classroom management. If the Social Studies teacher is able to manage his class well, then it is not difficult for the Social Studies teacher to achieve the learning objectives that have been formulated

\section{Obstacles Faced by Social Studies Teachers and Students in Implementing Outdoor- based Eco Literacy}

The results of surveys, interviews and document studies show that in general in junior high schools in Cirebon there are a number of problems with the Social Studies teacher regarding learning methods, includingthe selection of social studies learning methods that are less relevant to the objectives of the lesson and subject matter.Social studies teachers are less skilled in using learning methods.Social studies teachers are very much attached to one method.

Therefore, the use of methods in the implementation of social studies learning is very important to pay attention to so that the technique of presenting learning material to be used by social studies teachers when presenting appropriate and appropriate subject matter so that students do not feel bored with the lesson.

\section{Problems of Relationships Social Studies Teacher Education in Interacting with Students}

The relationship between social studies teachers and students or students in the teaching and learning process is a very determining factor. However good learning material is given, however, perfect the method used, but if the teacher's relationship with students is a relationship that is not harmo nious, it can create an undesirable outcome.

The problem that arises in the social studies teaching process is due to the lack of communication relations between the teacher and students and students and other students so that the interaction process becomes a vacuum. There are certain obstacles, for example, sometimes there is still an authoritarian attitude from the teacher, a closed attitude from the teacher, passive students, too many students, the education system, the circumstances and background of the teacher himself and his students.

One way to overcome this is through contact-hours in the teacher-student relation ship. Contact-hours or hours of meeting between the teacher-student, in essence, are activities outside the hours of presentation in front of the class as usual.In addition, all the democratic attitude and openness of the teachers need to be developed there needs to be active on the part of students and also must be friendly, students must also be polite. Each teacher needs to know the background of both the teacher and the students.

The teacher's task is how to design in order to create in order to create a more optimal teaching and learning process. The teacher should be able to develop more dynamic teaching and learning interactions to achieve the expected goals.

Other forms of learning activities other than through teaching in front of the class, other forms of learning need to be considered. The teacher can question and capture the situation of students and vice versa students submit various problems and obstacles that are being faced. A humanistic process of interaction and communication takes place. This clearly will greatly help the success of students'studies. Success in the sense of not just knowing or getting good grades in the exam, but will touch on the matter of mental attitude and behavior or things that are intrinsic.

Based on some of the descriptions above it can be understood, that when teachers do not interact with students routinely it will cause teaching and learning processes to be less smooth, and cause students to feel there is a distance from the teacher. So students are reluctant to actively participate in teaching and learning activities. 


\section{Problems of Social Studies Teachers in Learning Media}

The results showed in addition to the problems in terms of social studies classroom management, namely applying the learning method, there are other problems or obstacles that are often faced by teachers in implementing learning, namely the lack of use of media as a means of supporting social studies learning activities.

The word media comes from Latin and is a plural form of the word medium which literally means an intermediary or introduction. Media are various types of components in the student environment that can stimulate learning. Learning is a complex, complicated and unique process because it has certain characteristics/ characteristics that differ between one student and another. Therefore, learning is an individual problem, in the sense that learning will occur because the individual himself is doing it. The use of media in learning is very useful for teachers in terms of delivering subject matter to students. Because the media can facilitate the understanding of students in understanding material that is difficult to understand if only by listening to the teacher's explanation. Therefore, social studies teachers are also the media or even leave the media as learning aids.

However, teachers must be able to search for media and use these media to help implement the teaching and learning activities so that the goals set can be achieved.diverse skills, learning, and innovation, critical thinking and problem solving, communication and collaboration, and creativity and innovation; digital literacy skills include information literacy, media literacy and ICT literacy; career and life skills include flexibility and adaptability, initiative, social and cultural interaction, productivity and accountability, and leadership and responsibility [12](Trilling and Fadel, 2009). In the end, education produces a productive generation of the nation so that the problems of unemployment and competitiveness of human resources are minimized.
The teaching profession of social studies education in most of the schools studied in junior high schools in the city of Cirebon is not without problems, the teaching profession is a profession that requires creativity, innovation, and vision, including in developing teaching materials to attract students' interests. However, social studies teacher must be able to get out of all kinds of problems, the solution is a choice that does not harm you as a teacher as well as a drug for students to be able to accept the changes you create.

This makes it easier for social studies education teachers to find solutions to environmental problems where the problems they face are a repetition of those previously encountered. So in essence, it is not too difficult for teachers to make the right, effective and meet the goals including in developing the implementation of outdoor-based eco-literacy skills in social studies learning.

\section{CONCLUSIONS}

Based on the cases found by the researcher can be concluded as follow: most of the teachers are rarely to use eco-literacy and learning outdoor as the facilities should be given to the students. They think outdoor classroom learning is the time consumed.The implementation of outdoor learning in the social subject is very interesting. The students can use the environment as the tool and medium in the learning process. The teachers encourage the students to care to the natural environment as part of them. A number of problems with the Social Studies teacher regarding learning methods, including: selection of social studies learning methods that are less relevant to the objectives of the lesson and subject matter. Social studies teachers are less skilled in using learning methods. Social studies teachers are very much attached to one method.Therefore, the use of methods in the implementation of social studies learning is very important to pay attention too, so that the technique of presenting learning material to be used by social studies teachers when presenting appropriate with the subject matter so the students do not feel bored anymore. 


\section{ACKNOWLEDGMENTS}

The authors would like to thank the parties involved in environmental-based eco-literation research including environmental activists, social studies teachers in the city of Cirebon and environmental policymakers who contributed to researchers. The authors also thank to the rector of IAIN syekh Nurjati Cirebon through LPPM gave the fund for completing the research.

\section{REFERENCES}

[1] Locke. (2013). Environmental Education and Eco-literacy As Tools of Education forSustainable Developmen. Journal of Sustainability Education. 4.

[2] Zulfikli. (2014). Pengembangan Pendidikan IPS di SD. Bandung: UPI Press.

[3] Daniel. (2016). Airplane Aerodynamic. New York: Pitman Publishing Corporation.

[4] Lichona, T. (2012). Educating for Character (terjemahan). Jakarta: Bumi Aksara.

[5] Sumarlin. (2013). Persepsi dan Kepedulian Siswa terhadap Pengelolaan Lingkungan Sekolah. Yogyakarta:UGM Press.

[6] Spinola. (2013). Environmental Literacy Comparison Between Students Taughtin
EcoSchools Island Regionof Portugal. Science Education International, 26, pp. 395416.

[7] Creswell, J.W. (2013). Reseach Design (Pendekatan Kualitatif, Kuantitatif dan Mixed) Edisi Revisi. Yogyakarta: Pustaka Pelajar

[8] Creswell. (2013). Qualitative Inquiry and Research Design: Choosing among Five Approaches (3 $\left.{ }^{\text {rd }} . e d\right)$. Thousand Oaks, CA: Sage.

[9] Creswell, J.W (2013). Handbook of Qualitative Research. Yogyakarta: Pustaka Pelajar

[10] Moustakas, Clark (2014). Phenomenological Research Methods. New Delhi: Sage Publications.

[11] Jeynes, W. H. (2010). Religiosity, Religious Schools, and Their Relationship with theAchievement Gap: A Research Syn thesis and Meta-Analysis. The Journal of NegroEducation, pp. 263-279.

[12] Trilling, Bernie and Hood, Paul. (2009). 21 st Century Skills: Learning for Life in Our Times, John Wiley \& Sons. 978-0-47-0553626

[13] Pidarta. (2009). Landasan Pendidikan Konsep dan Aplikasinya. Jakarta: Rajawali Pers. 